\title{
The New Liberty
}

\section{Survival and Justice in a Changing World}

Ralf Dabrendorf. Director of the London School of Economics and a former Commissioner of the EEC, Dr. Dahrendorf is one of the leading sociologists of our time. Of these six lectures, comprising the 1974 BBC Reith Lectures, he explained: "I want to examine the condition of advanced societies, and the chance for its improvement in the light of real opportunities of human liberty. If we seem unable to solve our social, economic, and political problems-those of survival and justice-it is not our abilities which are at fault, but the ossified structures of a society in which progress so often turns into bureaucracy." He insists that to achieve a new liberty demands a broad change in the way we view history-a change from an orientation determined by expansion to one bent on improvement. April. About $\$ 5.95$

\section{Women in Chinese Society}

Margery Wolf \& Roxane Witke, Editors. This multidisciplinary work represents the first scholarly attempt to provide a baseline for understanding the massive changes in Chinese women's lives in our time. Topics include 17 th-century attitudes toward women, a rural "antimarriage" movement, women writers of the 1920's and 1930's, and the effect on rural women of the advent of the People's Republic. Studies in Chinese Society. $\$ 12.50$

\section{Indian and White}

\section{Self-Image and Interaction in a Canadian Plains Community}

Niels Winther Braroe. This is the first full-length study to approach the subject of contemporary Indian and White relations from a symbolic interactionist perspective. In analyzing the attitudes and behavior patterns of a small band of Cree Indians and the White ranchers and townspeople living nearby, it provides a unique view of the way each group maintains, without overt conflict, a sense of self-respect and ethnic identity. Illustrated. $\$ 8.50$

\section{Stanford University Press}




\section{Conflict Sociology}

\section{Toward an Explanatory Science}

\section{by RANDALL COLLINS}

In this important work, Randall Collins tries to remedy what he terms the excessive fragmentation and topicality of sociological research and the confusion of explanatory goals with ideological, practical, and aesthetic ones. He documents just what it is we know about explaining stratification, informal status cultures, sexual and age roles, organizations, politics, mobility, the distribution of wealth, and intellectual communities. The result is a unified view of what sociology is and should be: the author calls it "conflict sociology."

Specifically, the book is a four-pronged work that incorporates: a general explanatory theory for sociology; a non-ideological synthesis of the theoretical perspectives of Marx, Weber, and Goffman, along with accumulated empirical evidence; a unification of macro- and micro-perspectives; and an overview of the current scientific status of sociology.

CONFLICT SOCIOLOGY is a work that promises to stir up controversy in the academic community. It should be read not only by professionals and students of sociology, but also by political scientists, economists, anthropologists, and others interested in keeping abreast of the latest sociological perspectives.

1975,602 pp., $\$ 22.50 / £ 10.80$.

\section{Flight to America}

\section{by KRISTIAN HVIDT}

\section{$A$ Volume in the STUDIES IN SOCIAL DISCONTINUITY Series}

This book is primarily devoted to a study of the social conditions of the 300,000 Danes who emigrated to America before 1914, along with the background of the society they left. Based on personal data from 172,000 emigrants registered by Copenhagen police from 1868 to 1900 which was in turn sifted through computers, the book offers surprising and new statistical analyses. Then, by comparing the results with corresponding mațerial from Sweden, Norway, and other European countries, it manages to place the entire phenomenon into perspective.

A skillful blending of statistical information, observations on organization, mechanisms, and incentives of migration, and portrayals of personal experience-FLIGHT TO AMERICA will most likely become a prototype for future studies on mass movements.

1975,224 pp., $\$ 13.50 / £ 6.50$

Prices subject to change without notice.

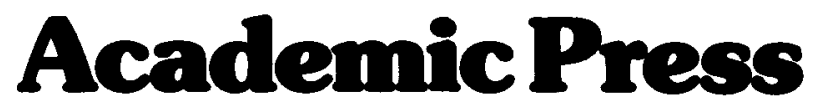

A Subsidiary of Harcourt Brace Jovanotich, Publishers 111 Fifth Avenue, New York, N.Y. 10003 24-28 Oval Road, London NW1 7DX 


\section{saom callöill}

\section{Internal Colonialism}

The Celtic Fringe in

British National Development, 1536-1966

Michael Hechter

In this study of what he terms the "Celtic Fringe", the author analyzes the relationship between England and the peripheral regions and explains the relative failure of Great Britain to develop as one nation. $\quad 300$ pages, $\$ 15.75$

Kingston, Jamaica

Urban Growth and Social Change, 1692-1962

Colin G. Clarke

This is the first detailed study of a Caribbean city. It examines the development of the social and spatial structures of Kingston from its founding in $\mathbf{1 6 9 2}$ to the independence of Jamaica in 1962.

384 pages, 131 line drawing, maps and halftones, $\$ 22.50$

sc UnIUEASTY OP CaUPOANIA PRESS BERHEIGY 9.4720

\section{The}

World

Today

\author{
C.J.A. Barratt \\ J.D.B. Miller \\ R.P. Sinha \\ Antonio de Figueiredo \\ Richard Burt
}

Annual Subscription:
The monthly journal of the Royal Institute of International Affairs provides the general reader with upto-date and authoritative information on current world problems

Developments in Southern Africa Changing balances in the Western Pacific Japanese foreign investment

The Portuguese dilemma

SALT after Vladivostok

\&4.75 post free (USA and Canada $\$ 15$ by accelerated surface post) 40p per copy (plus postage)

Orders may be sent to booksellers and newsagents, or to the Oxford University Press, Press Road, Neasden, London NWI0 ODD (Tel: 01-450 8080) 


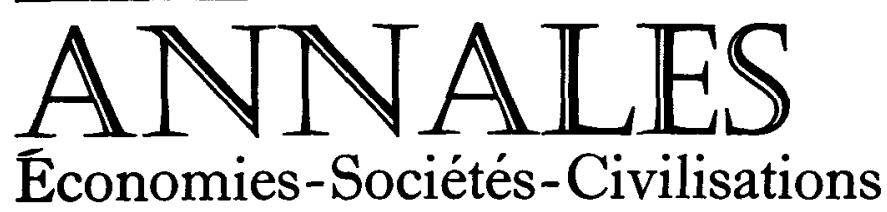

Revue bimestrielle, fondée en 1929 par Lucien FEBVRE et Marc BLOCH

Comité de Direction: Fernand BRAUDEL, Marc FERRO, Georges FRIEDMANN, Jacques LE GOFF, Emmanuel LE ROY LADURIE, Charles MORAZE

Secrétaires du Comité: Paul LEUILLIOT, Marianne MAHN-LOT

Secrétaire de la Rédaction: André BURGUIERE 3oe ANNEE-No. 2-3

MARS-JUIN 1975

REVISIONS

Guy CHAUSSINAND-NOGARE'T, Aux origines de la Révolution: noblesse et bourgeoisie

Louis BODIN, De Tours à Villeurbanne. Hypothèses pour une lecture renouvelée de l'histoire du Parti communiste français

LES DOMAINES DE L'HISTOIRE

Julius KIRSCHNER, Les travaux de Raymond de Roover sur la pensée économique des Scolastiques

Jean-Claude MARGOLIN, Des lunettes et des hommes ou la satire des mal-voyants au XVIe siècle

POLEMIQUES ET CONTROVERSES

Jacques DUPÂQUIER, Statistique et démographie historique

DOSSIER: HISTOIRE DE LA CONSOMMATION

Contribution à l'histoire de la consommation alimentaire XIVe-XIXe siècle (B. BENNASSAR et J. GOY); Pour l'histoire de l'alimentation: remarques de méthode (M. AYMARD).

Consommation alimentaire: - en Andalousie orientale (B. VINCENT); - d'Ancien Régime a Saint-Jacques-de-Compostelle (A. EIRAS ROEL et M. J. ENRIQUEZ MORALES); - des seigneurs auvergnats, XVe-XVIIIe siècle (P. CHARBONNIER); - dans le Haut Languedoc, XVIIe-XVIIIe siècle (J. VEDEL); - populaire, seconde moitié du XIXe siècle: l'Ecole de le Play (C. DAUPHIN et P. PÉZERAT); avariée à Paris, deuxième moitié du XIXe siècle (J. -P. ARON); - de la viande à Genève au XV́IIIe siècle (A.-M. PIUZ); - en Sicile, XIVe-XVIIIe siècle (M. AYMARD et H. BRESC); - usages alimentaires en Tunisie, XVIIIe-XIXe siècle (L. VALENSI).

L'alimentation: - des pensionnaires à la fin de l'Ancien Régime (W. FRIJHOFF et D. JULIA); - Viande et poisson au milieu du XIXe siècle (G. DÉSERT); - à Gand pendant la première moitié du XIXe siècle (C. VANDENBROEKE).

Niveaux de vis: - autour de Meaux, I700 et 1750 (M. BAULANT); - au Portugal, $1874-$ 1922 (M. HALPERN PEREIRA).

L'approvisionnement de Rome à l'époque moderne (J. REVEL). COMPTES RENDUS

A travers la France - Sociêtés médiévales

Rédaction: 54, Boulevard Raspail, 75006-Paris

Administration: Librairie Armand COLIN, 103, Boulevard Saint Michel, 75005

Paris

Comptes Chèques Postaux: PARIS, $\mathrm{N}^{\circ} 21$ 335-25

Abonnements: France et Pays de la Communauté: 90 F. (Étudiant France:

6o F.) Etranger: $100 \mathrm{~F}$.

Le numéro: $18 \mathrm{~F}$.-Numéros spéciaux: $36 \mathrm{~F}$. 


\section{STUDI STORIGI}

SOMMARIO del n. 4-1974

- L. Longinotti

FRIEDRICH ENGELS E LA « RIVOLUZIONE DI MAGGIORANZA $\gg$

- E. Cinnella

LA SOCIALDEMOCRAZIA E IL MOVIMENTO CONTADINO NELLA RIVOLUZIONE RUSSA DEL 1905

(continua)

OPINIONI E DIBATTITI

- T. Detti

LA RIVOLUZIONE D'OTTOBRE E L'ITALIA

- H. Mommsen

IL MOVIMENTO OPERAIO ORGANIZZATO E LA ASCESA DEI MOV. IMENTI FASCISTI NEL PERIODO FRA LE DUE GUERRE

PROBLEMI DI RICERCA

- G. Muzzioli

LE CAMPAGNE MODENESI DURANTE IL FASCISMO. SETTE ANNI DI CRISI : $1927-1933$

DOCUMENTI

- G. M. Bravo

I VIAGGI DI ENGELS IN ITALIA

NOTE CRITICHE

- M. Palla

LA CONQUISTA FAsCISTA DEL POTERE

- E. Collotti

STORIA MILITARE E STORIA POLITICA IN ALCUNE RECENTI opere sulla seconda guerRa mondiale CRONACHE

- G. Mori

IL VI CONGRESSO INTERNAZIONALE DI STORIA ECONOMICA (COPENHAGEN, 19-23 AGOSTO 1974)

- M. G. Rossi

COLLOQUIO SUL MOVIMENTO CATTOLICO ITALIANO (VENEZIA, 23-24-25 SETTEMBRE 1974)

- E. Ragionieri

MOVIMENTO OPERAIO E FASCISMO

SCHEDE

LIBRI RICEVUTI

\section{ABBONATEVI}

\section{Un fascicolo L. 2.500}

Direttori : Ernesto Ragionieri e Renato Zangheri

Direzione Redazione: Bologna, Via Barberia, $4^{2}$

AMministrazIONE: ROMA, Via dei Frentani, 4

Abbonamenti : anno L. 9.000, estero L. 12.000, un fascicolo L. 2.500

Versamenti: 8.G.R.A. - Via dei Frentani, 4 - c/c p. n. 1/43461 


\section{MINER VA}

\section{A REVIEW OF SCIENCE, LEARNING AND POLICY}

EDITOR: EDWARD SHILS

VoL. XIII, NO. 1

SPRING 1975

ARTICLES

The Academic Ethos under Strain

Edward Shils

The Development of a Professional Career in Science in France Maurice Crosland

Opposition to Technological Innovation

Allan Mazur

Women in American Science

Harriet Zuckerman and Jonathan R. Cole

REPORTS AND DOCUMENTS

The Intellectual Situation in German Higher Education

Walter Rüegg

BOOK REVIEWS

Henry Miller, John Ziman, Keith Pavitt

Annual subscription $\mathfrak{£ 5 . 0 0 / \$ 1 4 . 0 0}$

Single copy $£ 1.50 / \$ 4.20$

MiNERVA, 59 St. Martin's Lane, London WC2N 4JS 
Comparative Studies in Society and History is a forum for presentation and discussion of new research into problems of change and stability that recur in human societies through time or in the contemporary world. It sets up a working alliance between specialists in all branches of the social sciences and humanities. Debate and review articles bring the general reader in touch with current findings and issues.

\section{NOTES FOR CONTRIBUTORS}

Contributions may be descriptive, analytical or theoretical. Any article not in itself comparative may be accepted if it lends itself to comment that will place it in comparative perspective. Correspondence with the editors prior to the submission of articles will help to enable them to obtain such comment or a companion study. Emphasis in comparative studies may be either on similarities or, if these are significant enough and call for some recasting of generalisations, on differences. All contributions and editorial correspondence should be sent to the Editors, Comparative Studies in Society and History, Department of History, University of Michigan, Ann Arbor, Michigan 48104.

Two copies of each contribution, preferably accompanied by a stamped, addressed envelope, should be submitted. Both text and footnotes should be clearly typed with double spacing and wide margins; footnotes should appear on separate pages at the end of the article. Illustrations may be included by arrangement with the editors.

Contributors will receive 50 offprints bound in the journal covers. Any additional offprints must be ordered on receipt of the first proof.

ISI Tear Service, 325 Chestnut Street, Philadelphia, Pennsylvania 19106, U.S.A is authorized to supply copies of separate articles for private use only. 


\section{COMPARATIVE STUDIES IN SOCIETY AND HISTORY}

Editorial Foreword

\section{Frontier Settlements}

Martin T. Katzman The Brazilian Frontier in Comparative Perspective

Political Institutions and Social Policy

CARL Stone Political Determinants of Social Policy Allocations in Latin America

286-308

GABRIEL BEN-Dor Institutionalization and Political

Development: A Conceptual and Theoretical Analysis

\section{Education and Social Mobility}

W A L TER D. Connor Education and National Development in the European Socialist States: A Model for the Third World?

PATRICK J. HARRIGAN Secondary Education and the Professions in France During the Second Empire

\section{Ceremonial Space}

Mona Ozouf Space and Time in the Festivals of the French Revolution

(C) Society for the Comparative Study of Society and History, 1975

\section{Cambridge University Press}

Bentley House, 200 Euston Road, London NW1 2DB 32 East 57th Street, New York, N.Y. 10022

$£ 3.00$ net; US $\$ 9.00$ in U.S.A. and Canada 1975 subscription price $£ 9.00$ (US $\$ 27.00$ in U.S.A. and Canada) for institutions; $£ 5.50$ (US $\$ 14.00$ ) for individuals

Printed in Great Britain at the Alden Press, Oxford 